\title{
Pengaruh Kumulatif Cekaman Biotik dan Abiotik Terhadap Penurunan Pertumbuhan Tajuk Tanaman Kedelai [Glycine $\max ($ L.) Merr.] cv. Grobogan
}

\section{Cummulative Effect of Biotic and Abiotic Stress to the Shoot Growth Decrease of Soybean [Glycine max (L.) Merr.] cv. Grobogan}

\author{
Sri Darmanti \\ Departemen Biologi, Fakultas Sains dan Matematika, Universitas Diponegoro \\ Jl. Prof. Soedarto, SH, Tembalang, Semarang \\ Email : darmantisri@yahoo.co.id
}

Diterima 27 Juni 2016 / Disetujui 15 Agustus 2016

\begin{abstract}
ABSTRAK
Pada kondisi alami, tumbuhan sering terpapar pada kondisi beberapa cekaman biotik dan abiotik secara bersamaan. Tumbuhan merespon cekaman ganda dengan cara yang berbeda dibanding responya terhadap cekaman tunggal. Pengaruh cekaman ganda dapat ditunjukkan sebagai persen (\%) pengaruh kumulatif, yaitu perbandingan antara persen pengaruh cekaman ganda dengan persen pengaruh cekaman tunggal yang menyebabkan perubahan paling besar terhadap parameter yang diukur. Penelitian bertujuan mengkaji pengaruh kumulatif cekaman ganda biotik berupa interferensi gulma teki (Cyperus rotundus L.) dan abiotik berupa kekeringan terhadap penurunan pertumbuhan tajuk kedelai [Glycine max (L.) Merr. ] cv. Grobogan. Penelitian menggunakan metode ekperimental rancangan acak lengkap dua faktor (3 x 3), yaitu tingkat interferensi teki (kontrol, tiga teki, enam teki) dan tingkat cekaman kekeringan (kontrol, ringan, berat). Hasil penelitian menunjukkan pengaruh kumulatif cekaman ganda biotik dan abiotik dalam menurunkan pertumbuhan tajuk tanaman kedelai cv. Grobogan bersifat cross synergism yaitu salah satu dari kedua cekaman menyebabkan meningkatnya kepekaan tanaman kedelai cv. Grobogan terhadap cekaman yang lainnya.
\end{abstract}

Kata kunci : cross synergism, pengaruh, kumulatif, teki, kedelai

\section{ABSTRACT}

Under natural conditions, plants are often exposed to multiple stress conditions of some biotic and abiotic stress. Plants respond to a multiple stress are a different way than the single stress. Multiple stress effect can be shown as a percent (\%) cumulative effect, which is the ratio between the percent of multiple stress effect with single stress effect that cause most to the changes in the parameters measured. The purpose of this stud to assess the cumulative effects of multiple stresses of biotic stress such as Purple nutsege (Cyperus rotundus L.) interference and abiotic stress of drought on shoot growth decline of soybean [Glycine max (L.) Merr. ] Cv. Grobogan. Research was conducted using experimental method with a completely randomized factorial design $(3 \times 3)$. The first factor was purple nutsedge interference levels (control, three purple nutsedge, six purple nutsedge) and the second factor was drought stress levels (control, mild, severe). The results show that the cumulative effect of multiple stress of biotic and abiotic in reducing the growth of the shoot plant of soybean cv. Grobogan is cross synergism, is one of the two stress causes increased sensitivity of soybean plants cv. Grobogan to another stress.

Keywords : cross synergism, cummulative, effect, purple nutsedge, soybean

\section{PENDAHULUAN}

Banyak penelitian tentang cekaman biotik atau abiotik pada tumbuhan dilakukan hanya terhadap salah satu bentuk cekaman, tetapi pada kondisi alami tumbuhan sering terpapar pada cekaman ganda biotik dan abiotik (Pedrol et al., 2006; Akinson \& Urwin, 2012). Respon tumbuhan 
terhadap cekaman ganda biotik dan abiotik berbeda dibanding respon tumbuhan terhadap cekaman tunggal biotik atau abiotik (Mittler, 2006; Rejeb et al., 2014). Menurut Lehman and Blum (1999), hal tersebut dimungkinkan oleh adanya sentralisasi sistem respon pada tumbuhan, dengan demikian cekaman ganda harus dilihat sebagai satu bentuk cekaman baru yang berbeda dengan cekaman tunggalnya (Akinson \& Urwin, 2012). Menurut Alexieva et al. (2003), pengaruh cekaman ganda dapat ditunjukkan sebagai persen (\%) pengaruh kumulatif, yaitu perbandingan antara persen pengaruh cekaman ganda dengan persen pengaruh cekaman tunggal yang menyebabkan perubahan paling besar terhadap parameter yang diukur. Jika nilai persen pengaruh kumulatif lebih kecil dari $100 \%$, maka cekaman ganda tersebut bersifat cross adaptation yang berarti bahwa salah satu cekaman menyebabkan menurunnya kepekaan tanaman terhadap cekaman yang lainnya, sebaliknya jika nilai persen pengaruh kumulatif lebih dari 100\% maka cekaman ganda tersebut bersifat cross synergism yang berarti bahwa salah satu cekaman menyebabkan meningkatnya kepekaan tanaman terhadap cekaman yang lainnya.

Produksi kedelai secara nasional masih rendah (Anonim, 2012). Pada umumnya kedelai ditanam pada akhir musim penghujan, sehingga penyiangan gulma yang tidak sempurna yang menyebabkan persaingan berat antara tanaman kedelai dengan gulma dan rendahnya tingkat ketersediaan air tanah menjadi kendala biotik dan abiotik utama untuk meningkatkan produksi kedelai (Partohardjono, 2005; Atman, 2006; Anonim, 2009).

Gulma didefinisikan sebagai tumbuhan yang tumbuh pada tempat yang tidak dikehendaki (Kohli et al., 2006). Gulma dapat merugikan tanaman budidaya karena faktor kompetisi terhadap faktor tumbuh dan alelopati. Kedua faktor tersebut saling berkaitan dan sulit dipisahkan sehingga disebut sebagai "interferensi". Kompetisi terhadap air meningkatkan cekaman kekeringan, sedangkan sintesis dan akumulasi alelokimia distimulasi oleh kompetisi dan cekaman kekeringan (Qasem \& Foy, 2001; Morvillo et al., 2011).

Alelopati merupakan mekanisme interaksi antar tumbuhan melalui metabolit sekunder yang disebut alelokimia, yang berguna untuk adaptasi terhadap perubahan lingkungan. Alelokimia dapat menghambat pertumbuhan tumbuhan tertentu yang ada di sekitarnya (Edreva et al., 2008). Fenol merupakan senyawa utama yang berperan sebagai alelokimia dan dihasilkan tumbuhan dalam jumlah berlimpah (Narwal \& Sampietro, 2009). Berbagai bentuk cekaman biotik dan abiotik akan meningkatkan produksi Reactive Oxygen Species (ROS) yang mengakibatkan terjadinya cekaman oksidatif, yaitu bentuk kerusakan sel yang disebabkan oleh oksidasi lipid, protein dan DNA, sehingga mengakibatkan penurunan fungsi sel, menghambat pertumbuhan dan perkembangan sampai terjadi kematian tumbuhan (Gill \& Tuteja, 2010).

Tujuan penelitian ini adalah mengkaji pengaruh kumulatif cekaman ganda yaitu cekaman abiotik berupa interferensi teki (Cyperus rotundus L.) dan cekaman abiotik berupa kekeringan terhadap penurunan pertumbuhan tajuk tanaman kedelai [Glycine max (L.) Merr.] cv. Grobogan .

\section{METODE PENELITIAN}

\section{Bahan dan Alat Penelitian}

Benih kedelai [Glycine $\max ($ L.) Merr.] cv. Grobogan diperoleh dari Balai Penelitian KacangKacangan dan Umbi-Umbian (BALITKABI) Malang Jawa Timur. Umbi teki (Cyperus rotundus L.) diperoleh dari persawahan di kecamatan Tinjomoyo, Semarang.

\section{Disain Penelitian}

Penelitian menggunakan metode ekperimental rancangan acak lengkap dua faktor ( 3 X 3), yaitu faktor cekaman kekeringan $\mathrm{K}_{0}=$ kontrol (FTSW 1), $\mathrm{K}_{1}=$ ringan $(F T S W 0,5)$ dan $\mathrm{K}_{2}=$ berat $(F T S W 0,25)$ dan faktor interferensi teki, yaitu $\mathrm{T}_{0}=$ kontrol $\left(0\right.$ teki), $\mathrm{T}_{1}=$ tiga teki dan $\mathrm{T}_{3}=$ enam teki, tiap unit perlakuan dengan 5 ulangan. 


\section{Penanaman dan Perlakuan}

Benih kedelai diseleksi, dipilih yang mempunyai ukuran seragam. Umbi teki dipilih yang mempunyai berat seragam, disemaikan dan dipilih yang mempunyai 1 mata tunas. Penanaman kedelai dan teki dilakukan pada waktu bersamaan di dalam pot plastik diameter $25 \mathrm{~cm}$, tiap pot berisi $3 \mathrm{~kg}$ media tanam berupa tanah latosol dan diberi pupuk dasar $1 \mathrm{~g}$ TSP, 0,5g KCL dan 0,3g urea. Tiap pot ditanami satu kedelai dan teki dengan jumlah sesuai perlakuan. Perlakuan cekaman kekeringan 2 minggu sampai 5 minggu setelah tanam.

\section{Penentuan Cekaman Kekeringan}

Perlakuan cekaman kekeringan ditentukan berdasarkan nilai The fraction of Ttranspirable Soil Water (FTSW) (Haineman et al. 2011; Darmanti et al., 2016 ${ }^{\mathrm{a}}$ ). Diperoleh berat pot beserta tanaman pada $\mathrm{K}_{0}: 4,2 \mathrm{~kg}, \mathrm{~K}_{1}: 3,8 \mathrm{~kg}$ dan $\mathrm{K}_{2}: 3,6$ $\mathrm{kg}$. Penyiraman dilakukan setiap hari, jumlah air yang disiramkan ditentukan dengan menimbang pot beserta isinya sampai berat sama dengan berat seperti perlakuan.

\section{Penentuan Persen (\%) Pengaruh Kumulatif Cekaman Ganda}

Penentuan persen pengaruh kumulatif cekaman ganda dengan rumus Alexieva et al. (2003) sebagai berikut :

$\mathrm{PK}=\frac{(A+B)}{B} \times 100$

Keterangan :

a. PK : \% pengaruh kumulatif cekaman ganda .

b. A : perubahan yang disebabkan oleh cekaman A.

c. B : perubahan yang disebabkan oleh cekamanan B (cekaman yang menyebabkan perubahan lebih besar dibanding cekaman A)

d. $(\mathrm{A}+\mathrm{B})$ : perubahan yang disebabkan oleh cekaman ganda $\mathrm{A}$ dan $\mathrm{B}$.

\section{HASIL DAN PEMBAHASAN}

Menurut penyebabnya, cekaman
dibedakan atas cekaman biotik dan abiotik.
Cekaman biotik disebabkan oleh hasil aktivitas organisme lain, sedang cekaman abiotik disebabkan oleh kelebihan atau defisit fisik atau kimia lingkungan (Apel \& Hirt, 2004). Tumbuhan yang mendapat cekaman biotik maupun abiotik pada umunya akan mengalami penurunan kecepatan proses fisiologis seperti absorpsi air dan hara, fotosintesis, respirasi, pertumbuhan, perkembangan dan reproduksi (Pedrol et al., 2006). Dilaporkan oleh Darmanti dkk. (2016b), bahwa cekaman ganda biotik berupa interferensi teki dan abiotik berupa kekeringan menyebabkan menurunkan bobot basah, bobot kering dan panjang tajuk tanaman kedelai cv. Grobogan.

Analisis terhadap pengaruh kumulatif cekaman ganda interferensi teki dan kekeringan terhadap penurunan pertumbuhan tajuk kedelai cv. Grobogan yang ditunjukkan dengan parameter bobot basah tajuk (Gambar 1), bobot kering tajuk (Gambar 2) dan panjang tajuk (Gambar 3) pada semua kombinasi perlakuan menunjukkan nilai lebih $100 \%$ atau bersifat cross synergism. Hal tersebut diartikan bahwa salah satu dari kedua cekaman menyebabkan meningkatnya kepekaan tanaman kedelai cv. Grobogan terhadap cekaman yang lainnya (Alexieva et al., 2003)

Hal ini sesuai dengan hasil penelitian Purwanto dan Agustono, (2010), yang menyatakan bahwa kompetisi kedelai dengan teki pada kepadatan teki 5, 10, 15 dan 20 per pot menurunkan luas daun, lebar stoma, kandungan klorofil, laju transpirasi dan laju fotosintesis tanaman kedelai. Perlakuan cekaman kekeringan yang terjadi bersamaan dengan kompetisi antara kedelai dengan teki memperberat pengaruh kompetisi terhadap pertumbuhan kedelai yang ditunjukkan dengan semakin besarnya penurunan luas daun, laju transpirasi, kandungan klorofil, laju fotosintesis dan lebar bukaan stoma pada tanaman kedelai yang mendapat perlakuan ganda kompetisi dan kekeringan dibanding dengan tanaman kedelai yang hanya mendapat perlakuan kompetisi. Sebaliknya Sanchez-Morerias et al. (2008) melaporkan bahwa perlakuan benzoxalin-2(3H)one (BOA) dapat menghilangkan sifat toleran Lactuca sativa terhadap salinitas. 


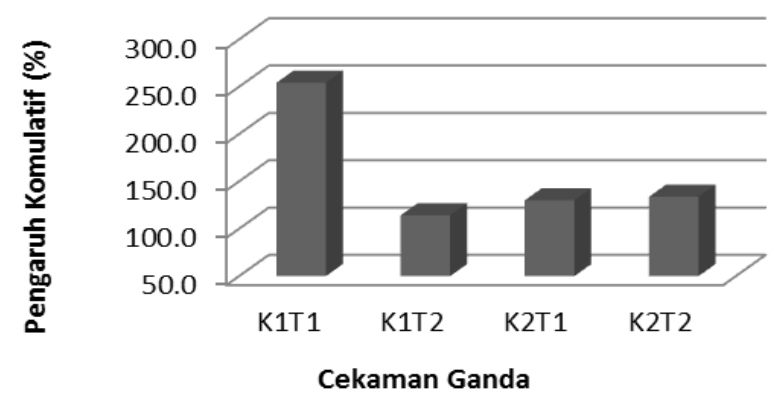

Gambar 1. Cross synergism (>100) pengaruh kumulatif cekaman ganda interferensi teki (Cyperus rotundus L.) dan kekeringan terhadap bobot segar kedelai [Glycine max (L.) Merr. cv. Grobogan].

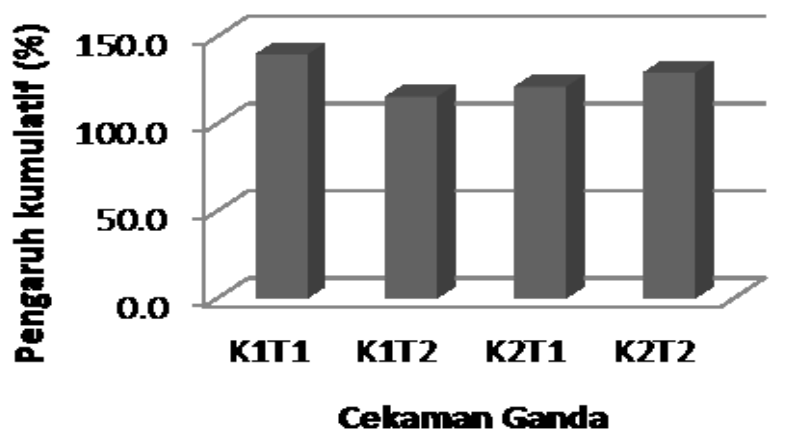

Gambar 2. Cross synergism (>100) pengaruh kumulatif cekaman ganda interferensi teki (Cyperus rotundus L.) dan kekeringan terhadap bobot kering kedelai [Glycine $\max$ (L.) Merr. cv. Grobogan].

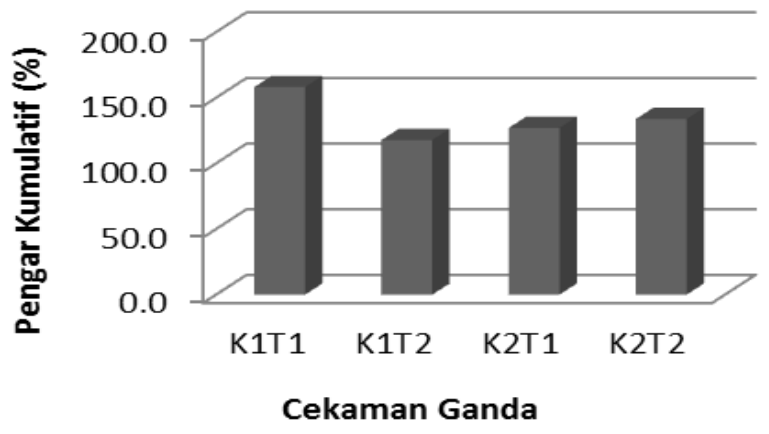

Gambar 3. Cross synergism (>100) pengaruh kumulatif cekaman ganda interferensi teki (Cyperus rotundus L.) dan kekeringan terhadap panjang tajuk kedelai [Glycine max (L.) Merr. cv. Grobogan].

Menurut Mittler (2006) dan Akinson \& Urwin (2012) pada kondisi cekaman ganda biotik dan abiotik, cekaman abiotik dapat dapat menyebabkan penurunan atau peningkatan kepekaan tanaman terhadap cekaman biotik atau sebaliknya. Selanjutnya dikatakan oleh Alexieva et al. (2003) dan Li \& Gong, (2011), bahwa cekaman ganda dapat meningkatkan pengaruh negatif pada tumbuhan, sehingga jauh melebihi total pengaruh negatif yang ditimbulkan oleh semua faktor cekaman yang mengenainya. Pada kasus tertentu tumbuhan yang semula terpapar faktor cekaman 
tunggal mampu meningkatkan resistensinya terhadap cekaman lain yang terjadi kemudian.

\section{SIMPULAN}

Dari penelitian ini dapat disimpulkan bahwa pada cekaman ganda interferensi teki dan kekeringan terhadap pertumbuhan tajuk kedelai cv. Grobogan bersifat cross synergism atau salah satu dari kedua cekaman menyebabkan meningkatnya kepekaan tanaman kedelai cv. Grobogan terhadap cekaman yang lainnya.

\section{DAFTAR PUSTAKA}

Akinson, N.J. and P. E. Urwin. 2012. The Interaction of Plant Biotic and Abiotic Stresses : From Genes to The Field. Journal of Experimntal Botany. 63 : 35233543.

Alexieva, V., S. Ivanov, I. Sergiev and E. Karanov. 2003. Interaction Between Stresses. Bulgarian Journal of Plant Physiology. Special Issue.: 1-17.

Apel, K. and H. Hirt. 2004. Reactive Oxygene Species : Metabolism, Oxidative Stress and Signal Transduction. Annual Review of Plant Biology 55 : 373-399.

Atman, 2006. Pengelolaan Tanaman Kedelai di Lahan Kering Asam. Jurnal Ilmiah Tambua. $3: 281-287$.

Anonim, (2012). Pedoman Teknis Pengendalian Produksi Tanaman Kedelai. Direktoral Jendral Tanaman Pangan. Kementerian Pertanian. Republik Indonesia.

Anonim. 2009. Petunjuk Teknis Pengelolaan Tanaman dan Sumberdaya Terpadu (PTT) Kedelai. Balai Pengkajian Teknologi Pertanian (BPTP). Jawa Barat.

Darmanti, S., Santosa, Kumala D. and Hartanto, N. 2016a. Antioxidative Defenses of Soybean [Glycine max (L.) Merr. cv. Grobogan] Against Purple Nutsedge (Cyperus rotundus L.) Interference during Drought Stress. Journal Animal and Plant Sciences. 26(1):225-232.
Darmanti, S. 2016. Penurunan Pertumbuhan Tajuk Kedelai [Glycine max (L.) Merr.] Akibat Cekaman Ganda Interferensi Teki (Cyperus rotundus L.) Dan Kekeringan. Buletin Anfis . Vol. XXIV No. 1.

Edreva, A., V.Velikova, T. Tsonev, S. Dagnon, A. Gurel, I. Aktas and E. Gesheva. 2008. Stress-Protective Role of Secundary Metabolites : Diversity of Fuction and Mechanisms. General and Applied Plant Physiology. 34: 67-78.

Gill, S.S. and N. Tuteja. 2011. Reactive Oxygen Species and Antioxidant Machinery in Abiotic Stress. Plant Physiology and Biochemistry. 48 : 909-930.

Hainemann, A.B., L.F. Stone and N.K. Fageria. 2011. Tranpiration Rate Response to Water Deficit During Vegegtative and Reproductive of Upland Rice Cultivars. Scentia Agricola. 68 : 24-30.

Kohli, R.K., D.R. Batish and H.P. Singh. 2006. Allelopathic Interaction in Agroecosystems. Pp 465 - 494. In M.J. Reigosa, N. Pedrol and L. Gonzales (eds.). Allelopathy : A Physiological Preocess with Ecological Implicartion. Springaer. Netherlands.

Lehman, M..E. and U. Blum. 1999. Influence of Pretreatment Stresses on Inhibitory Effects of Ferulic Acid, an Allelopathic Phenolic Acid. Journal Chemicals Ecology. 25 : 1517-1529.

Mittler R., 2006. Abiotic Stress, The field Enviroment and Stress Combination. Trend in Plant Science. $11:$ 15-19.

Morvillo, C.M., E.B. de la Fuente, A. Gil, M.A. Martinez-Ghersa and J.I. GonzalezAndujar. 2011. Competitive and Allelopathic Interference between Soybean Crop and Annual Wormwood (Artemesia annua L.) under Field Conditions. European Journal of Agronomy. $34: 211-221$.

Narwal, S.S. and D.A. Sampietro. 2009. Allelopathy and Allelochemicals. Pp. 3-5. In D.A.Sampietro, C.A.N. Catalan, M.A. 
Vattuone and S.S. Narwal. (eds.). Isolation, Identification and Characterization of Allelochemicals/Natural Products Science Publishers, Plymouth.

Partohardjono, S. 2005. Upaya peningkatan produksi kedelai melalui perbaikan teknologi budidaya. Pp.132-147. Dalam Partohardjono (penyunting). Analisa dan Opsi Kebijakan Penelitian dan Pengembangan Tanaman Pangan. Monograf No.1 2005 Puslibang Bogor.

Pedrol, M..N., I. Gomzales and M.J. Reigosa. 2006. Allelopathy and Abiotic Stress. In M.J. Reigosa, N.Pedrol and L. Gonzales. (eds.). Allelopathy : A Physiological Preocess with Ecological Implicartion.Springer. Netherlands.

Purwanto dan T. Agustono. 2010. Kajian Fisiologi Tanaman kedelai pada berbagai kepadatan gulma teki dalam kondisi cekaman kekeringan. Jurnal Agroland. 17 : 85-90.

Qasem, J.R. and C.L. Foy. 2001. Weed Allelopathy : Its Ecological Impacts and Future Prospects. Journal of Crop Production. 4 : 43-119.

Rejeb, I.B., V. Pastor and B. Mauch-Mani. 2014. Plant Responses to Simultaneous Biotic and Abiotic Stress : Molecular Mechanism. Plants $3: 458-475$.

Sanchez-Morerias, A.M.., N. Pedrol, L. Gonzales and M.J. Reigosa. 2008. 2-3HBenzoxazolinone (BOA) Induces Loss of Salt Tolerance in Salt-Adapted Plants. Plant Biology. 11 : 582-590. 